\title{
SEASONAL WATER CRISES AND SOCIAL DILEMMAS IN SEMI-ARID AREAS OF THE LAKE ZONE OF TANZANIA
}

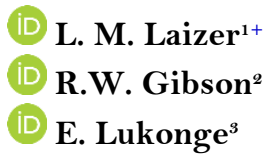

Article History

Received: 8 March 2018 Revised: 30 March 2018 Accepted: 6 April 2018 Published: 16 April 2018

\section{Keywords}

Informal water governance Dry sandy riverbeds Common property Irrigation.

\author{
${ }^{1,3}$ Lake Zone Agricultural Research and Development Institute, Ukiriguru, \\ Tanzania \\ ${ }^{2}$ Email:lembrisl@gmail.com Tel: +255756098987 \\ ${ }^{3}$ Email:elukonge@yahoo.com Tel:+255754430675 \\ ${ }^{2}$ Natural Resources Institute, University of Greenwich, Chatham Maritime, \\ Kent, ME4, 4TB,UK \\ ${ }^{2}$ Email:r.w.gibson@gre.ac.uk Tel:+44(O) 16348832.54
}

ABSTRACT
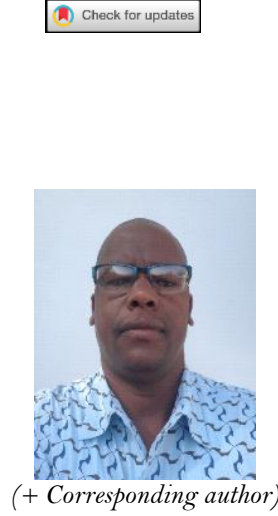

(+ Corresponding author)

\begin{abstract}
The absence of formal institutions regulating water resources indicated a need to examine how informal governance works in semi-arid areas of the Lake Zone of Tanzania. Ostrom's theory of common property resources was adapted to develop a questionnaire administered to 162 households using five different water sources (lake/dam, ponds near lake/dam, ponds, wells and waterholes) along with focus group discussions (6), key informant interviews (33) and field observations. The results indicated that communities do not have water management systems where water is abundant (lake/dam and ponds near these water sources). Conversely, where water is scarce (ponds, wells and water holes), communal water management occurs. However, such communal water governances are location specific and limited and, though they appear to function well at preventing water exhaustion, they fail to resolve the complex social dilemmas in that ecological system. Thus, most water resources are dominated by households with sound economic resource base, they take deliberate efforts to establish private wells in wetlands to intercept underground resources, raising issues of equity, contamination of underground water resources and human safety. Sandy river beds seemed to represent the worst 'tragedy' of unmanaged common resources, often being located in 'no-man's land' between districts or regions, with uncontrolled competition resulting in enormous water holes dug by local resource users from both sides, and exhaustion by those with the deepest waterholes and access to engine-driven pumps. There are two water main crises: (1) too little is available to meet the current demand during an annual prolonged dry season (6-7 months) and (2) increasing social dilemmas on how to manage the little available. How external interventions could address these issues is discussed.
\end{abstract}

Contribution/ Originality: This paper analyses the role of communal water management institutions in the semi-arid of the Lake Zone Tanzania where resource availability dramatically varies by season. Local rules and norms exist but often fail to resolve social dilemmas in complex social-ecological systems. How external interventions could address these challenges is discussed.

\section{INTRODUCTION}

Water plays an important role in livelihoods and ecosystems but there is a growing concern on its scarcity, with $60 \%$ of people in the world facing this for several months each year (Mekonnen and Hoekstra, 2016). Agriculture has historically been the main consumer, accounting for nearly $63 \%$ of the total global fresh water use; 
a worst case scenario is that its rate of use will increase at nearly twice that of the human population (Food and Agriculture Organization of the United Nations (FAO), 2015). The situation is particularly acute in developing countries, where there are often poor infrastructures, unregulated underground water extraction and a rapid increase in population, (de Fraiture and Giordano, 2014; Mekonnen and Hoekstra, 2016). Indeed, in South and East Asia, most shallow aquifers have been exhausted by small-scale private irrigators using tube wells. In India for instance, the area under irrigation has increased in a few decades by $500 \%$, driven by largely unregulated irrigators supported by subsidized electricity for pumping water using tube-wells (Shah, 2009). The population, however, has also increased dramatically and unregulated marketing of water to meet domestic demand in urban centers has led to a decline $(53 \%)$ in water availability for agricultural use (Packialakshmi et al., 2011). A recent study in Bangladesh has mirrored these water management challenges (Sakiur et al., 2016).

Similar trends are being observed in Sub-Saharan Africa. The current population (nearly 1 billion) is expected to double by 2050 (Ittersum et al., 2016). Rainfall in the rainy season is often erratic and farmers are increasingly using small-scale irrigation during the dry season, with an estimated 113 to 369 million small-scale irrigators, expected to at least double by 2050 (Xie et al., 2014). Whether such increases will be an opportunity for economic growth or will unsustainably deplete underground water resources will depend on how the water resources are shared, along with policy interventions to already degrading water resources (de Fraiture and Giordano, 2014). The semi-arid areas of the Lake Zone of Tanzania have received little attention on water management issues and the key question is: Will largely unregulated increase in the number of small private irrigators be a way out of poverty or will it eventually cause poverty as has so often happened elsewhere in the developing world?

\subsection{Water Management Systems}

Global initiatives for the development of sustainable management strategies of water resources largely originating from developed countries through international agencies such as World Bank have included the development of institutions (North, 1990). These can be formal or informal: formal ones refer to written legal entities whereas informal ones involve traditional systems often rooted in the cultural pluralisms governing homogeneous tribal societies (North, 1990; Ostrom, 1990). Both formal and informal water management systems occur in developing countries; however, they do not necessarily complement each other and lead to sustainability (Jenniver, 2007; Hu et al., 2014; Weiss, 2015).

\subsubsection{Formal Water Management Institutions}

The increasing water crises in developing countries has raised global attention to formal water laws and policies, with most developing countries being advised to include integrated water resource management (IWRM) principles in their existing laws (Global Water Partnerships (GWP), 2012). In Tanzania for instance, Water Policy 2002 and Water Act \# 9 of 2009 regulate water use in the country (United Republic of Tanzania (URT), 2013) with water allocated primarily to humans, secondarily to the ecosystem and thirdly to economic use. Among economic uses, first priority is to agriculture (crop irrigation and stock watering) (URT, 2013). However, IWRM principles have been debated for decades in developing countries with limited tangible results and it has been strongly argued that these principles were driven by political agenda including those of donors and water policies have been seen as an opportunity to attract funding rather than encourage the evolution of useful institutions (Swatuk, 2005; Giordano and Shah, 2014). For instance, formal regulation fragmented existing traditional norms and rules in Yemen (Weiss, 2015) and formal water users associations (WUAs) had conflicts of interest with traditional water governance systems in several arid areas of northwest China (Hu et al., 2014). Similar failures of WUAs have been documented in West Africa (Kyei-Buffour and Ofori, 2006) and in Tanzania they failed to pay fees to access water in the Mkoji sub-catchment (Mehari et al., 2009). Indeed, Tanzania has struggled to regulate its limited water 
resources and informal water governance is now being appraised much more for the sustainable management of common property resources including small scale irrigation water management (Caretta, 2015; Mosha et al., 2016).

\subsubsection{Evolution of Informal Water Management Institutions}

The common property resource theory suggests that increasing scarcity is an incentive for community collaboration, and leads to the evolution of informal water governance and sustainable resource management (Ostrom, 1990). Eight principles of self-governance were developed (Ostrom, 1990; Ostrom and Basurto, 2011) and literature reviews have assessed the effectiveness of community-based institutions in addressing social dilemmas in developing countries, notably in water equity/ efficiency tradeoffs between small-scale upstream and downstream irrigators accessing water from permanent rivers (Quinn et al., 2007; Sjaha and Baldwin, 2014; Caretta, 2015; Weiss, 2015; Mosha et al., 2016). However, little is known on water governance systems in communities living in semi-arid areas where rivers are seasonal. According to Quinn et al. (2007) resource availability dramatically varies by season in semi-arid areas of central Tanzania (Singida and Dodoma): resource users are operating in a complex social and economic system and therefore Ostrom's principles should not be used as blueprint. These communities depend on run-off waters accumulated in natural and manmade reservoirs, with diverse water extraction technologies used in wetlands and in dry sandy riverbeds. Local resource users (domestic, stock and crop use) also compete and communities face fluctuating water availability, which must affect the development of permanent local institutions. This study therefore sought to carry out a socio-economic analysis of water governance systems in semi-arid areas of the Lake Zone of Tanzania, in order to determine the existence and functioning of informal water governance systems there.

\section{MATERIALS AND METHODS}

The study was conducted in Meatu, Misungwi and Shinyanga Rural districts (Figure 1) in the Lake Zone of Tanzania. Very approximately, the three locations are located between latitude $2.84^{\circ}$ and $3.68^{\circ} \mathrm{S}$ and between longitudes $33.08^{\circ}$ and $34.68^{\circ} \mathrm{E}$. Their population totals nearly 1.2 million and they occupy $8,211 \mathrm{~km}^{2}$ (National Bureau of Statistics (NBS) (2012). The three locations were selected because they are semi-arid with a dry season lasting about 6 months (mid-May to mid-November); conversely, flooding may occur during the rainy season. As in many other arid and semi-arid areas of Sub Saharan African region, rainfall is also highly unpredictable and erratic, and agricultural opportunities are limited. Small petrol-powered pumps are starting to be used and farmers are increasingly seeking improved livelihoods using water resources for horticultural crop production during the dry season including, sweetpotato seed conservation and livestock grazing. Sweetpotato is among the main food staples and considered as hunger breaker when other staples fail but seed multipliers need water to conserve and multiply planting material during the dry season. Thus, use of water during the dry season is a pre-condition for seed availability at the onset of the rainy season. Multipliers are relying on underground water sources which are recharged seasonally by rain and floods (Lukonge et al., 2015). 


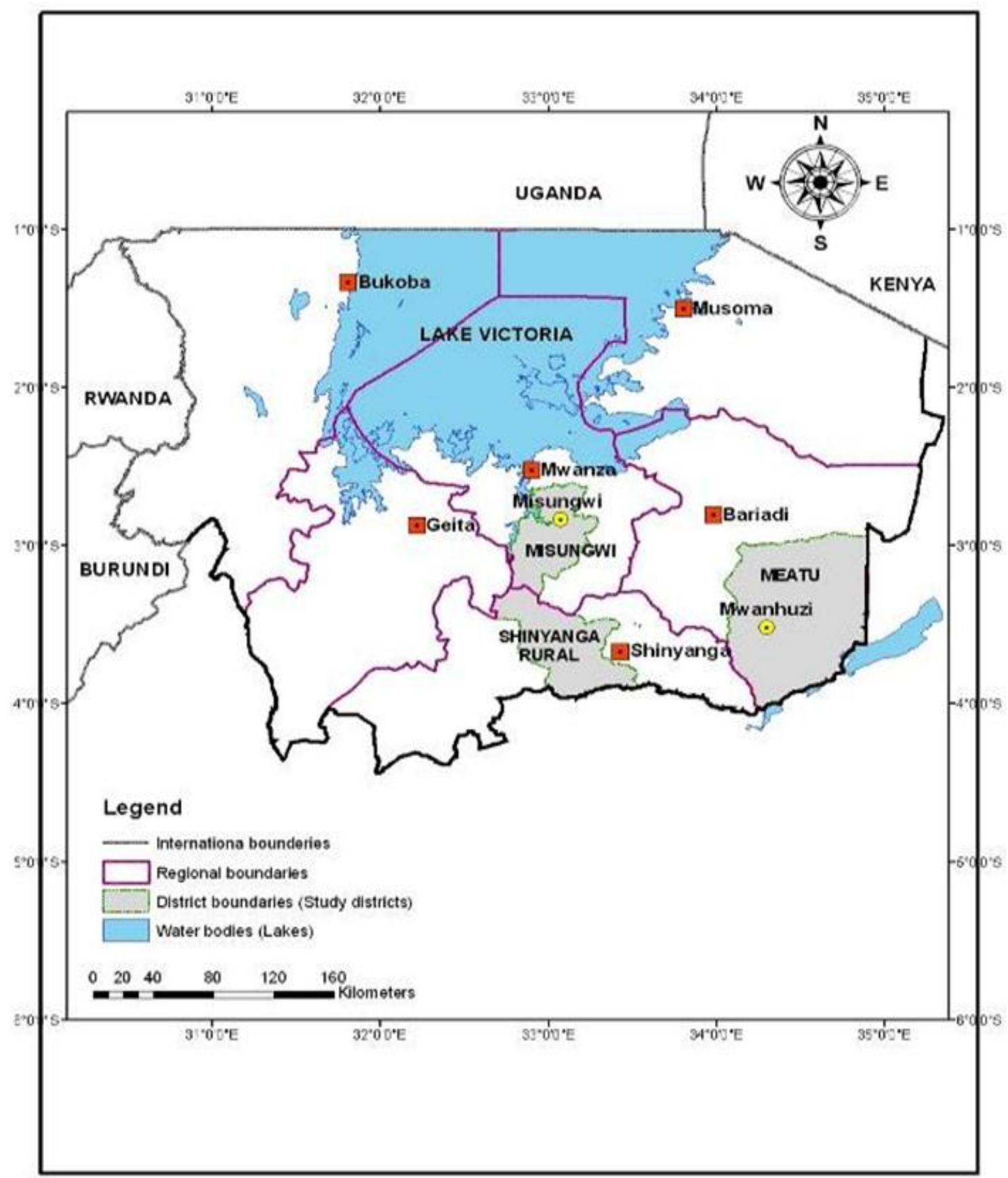

Figure-1. Map of Lake Zone Tanzania showing large surface water resources in study districts, and red squares show regional administrative offices regulating water at basin level (Bariadi, Bukoba, Geita, Musoma, Mwanza and Shinyanga).

\subsection{Sample Selection}

The types of water resources were the main independent variables measuring actual water availability and the local governance structures regulating abstraction were the dependent variables. This study used a stratified sampling technique and involved mapping and describing the water resources available in the three districts based on water scarcity. This was achieved through published literature, government resources (Zonal Irrigation Engineer and district authorities) and researcher experience in working with the local communities for over one decade. Lake Victoria, major reservoirs (dams), ponds, wells and waterholes dug in sandy beds of dry seasonal rivers were the main water resources available and their detailed characteristics were described (Table 1). 
Table-1. Different water resources, their characteristics and their main inlet/outlet in this study area of semi-arid areas of Lake Tanzania

\begin{tabular}{|c|c|c|}
\hline Type of water resource & Main Characteristics & Feed/outlet \\
\hline Lake & $\begin{array}{l}\text { Lake Victoria basin, largest fresh water resource } \\
\text { in the Sub Saharan Africa region, with } \\
\text { approximately surface area of } 68,900 \mathrm{~km} \text {, serving } \\
\text { about } 30 \text { million population in the region (Tong et } \\
\text { al., 2016) The Gulf of Lake Victoria extends to } \\
\text { South East Misungwi (Figure 1). }\end{array}$ & $\begin{array}{l}\text { Main inlet is perennial } \\
\text { rivers flows and surface } \\
\text { runoff; outlet is the Nile } \\
\text { that extend to Egypt and } \\
\text { Sudan. }\end{array}$ \\
\hline $\begin{array}{l}\text { Dam and ponds near } \\
\text { lake/dam }\end{array}$ & Large water storage, can be manmade or natural. & $\begin{array}{l}\text { Seasonal runoffs and } \\
\text { underground water table. }\end{array}$ \\
\hline $\begin{array}{l}\text { Pond near large surface } \\
\text { waters (Lake/dam) }\end{array}$ & $\begin{array}{l}\text { Locally known as malambo, these are water } \\
\text { reservoirs (smaller than dam) used to collect } \\
\text { runoff and may lead to large water sources } \\
\text { (Lake/Dam). }\end{array}$ & $\begin{array}{l}\text { Runoff during rainy season, } \\
\text { with or without outlet } \\
\text { leading to large surface } \\
\text { water sources. }\end{array}$ \\
\hline Pond & $\begin{array}{l}\text { Also known as malambo, these are water reservoirs } \\
\text { (also called pan/charcoal dam) used to collect } \\
\text { runoff. They can be manmade such as those made } \\
\text { along main highways by excavators or natural } \\
\text { depressions along seasonal rivers. }\end{array}$ & $\begin{array}{l}\text { Runoff during rainy season, } \\
\text { no outlet. }\end{array}$ \\
\hline Well & $\begin{array}{l}\text { Mostly wide diameter and unlined hand dug wells } \\
\text { to access shallow ground water (normally within } \\
10 \mathrm{~m} \text { depth). Modern wells are smaller diameter } \\
\text { (dug using drilling rig), lining material and a hand } \\
\text { pump. There also naturally occurring well in } \\
\text { wet/swamp areas. }\end{array}$ & Underground water table. \\
\hline $\begin{array}{l}\text { Waterhole in dry sandy } \\
\text { river bed }\end{array}$ & $\begin{array}{l}\text { Temporary hole dug in the middle of dry sandy } \\
\text { riverbeds, washed away by floods every rainy } \\
\text { season. }\end{array}$ & Water held within sand \\
\hline
\end{tabular}

Source: adapted from FAO (2010); URT (2013) and during discussion with Zonal Irrigation Engineer

Misungwi's eastern border lies on a gulf of Lake Victoria with access to the abundant water resources of the largest (estimated area 68,900 $\mathrm{km}^{2}$ ) fresh water lake in Sub Saharan Africa (Tong et al., 2016). Both Shinyanga and Meatu districts have one large surface dam and wetland lying approximately in the north west and south east respectively (Figure 1). Elsewhere in the districts, communities rely on small water reservoirs such as natural ponds, shallow wells and waterholes dug in sandy riverbeds to sustain their livelihoods during the period of water scarcity. The second stage involved purposively selecting 5 villages per district based on the presence of the different water resources ( 1 village per water resource per district) and in addition, 2 villages with relatively large ponds near large surface waters were also selected. As a result, a total of 17 villages were selected (Table 2 ). The third stage involved identifying a sampling frame in each village from among all households accessing water from a sampled water resource. A household list was obtained from village executive officers (VEOs) and ' $n z e n g o$ ' leaders, and with help of local extension agents, a random sample of 175 household (Table 2) was selected.

Table-2. Households sampled with respect to access to water type, sampling intensity and household size.

\begin{tabular}{l|l|l|l|l}
\hline Type of water resource & Villages & Households accessing water & Sampling Intensity (\%) & $\begin{array}{l}\text { Sample size } \\
\text { (households) }\end{array}$ \\
\hline Lake/dam & 3 & 699 & 4 & 30 \\
\hline Pond near Lake/dam & 2 & 276 & 7 & 20 \\
\hline Pond & 5 & 1,065 & 4 & 48 \\
\hline Well & 3 & 105 & 4 & 40 \\
\hline Waterhole* & 4 & 1,248 & & 45 \\
\hline Total & 17 & 3,393 & & 175 \\
\hline * In the middle of dry sandy riverbed. Source: This study
\end{tabular}

\subsection{Data Collection}

Household survey: A questionnaire including both open- and closed-ended questions was designed to collect data through a face-to-face interview with individual households for the household survey; it was pre-tested in 
Misungwi district. The first part of the questionnaire covered biographical information of respondents (i.e. gender, age, level of education, etc.). The second part assessed water governance across the 5 types of water resource and the sources of infrastructures of each resource. Each respondent was asked how each water resource was owned; open ended as well as closed questions were ask about community perceptions of water scarcity and the causes of water scarcity. The third part was derived from Ostrom's principles on good water governance (Ostrom, 1990) and asked each household whether there was any regulation of water for domestic, stock or crop use for each water extraction technologies available. These required 'No' or 'Yes' responses followed by extended 'what, why and how' questions.

Focus Group Discussions (FGD) and Interviews of Key Informants; Two checklists were used to interview 48 farmers in small groups of 5-10 members (2 groups per district) and 36 key informants (Zonal Irrigation Engineer (1), District Irrigation Officers (3), village leaders (15), Ward Extension Agents (15), and NGOs representatives (2)). The main purpose of FGDs and consulting the formal government sector was to verify the information collected from the household survey (Maxwell, 2013) and explore issues across the systems such as sharing a resource (water) across village, district and regional boundaries, notably sandy riverbeds lying along district or regional boundaries and containing water. Complex socio-ecological systems often need external support to resolve (Ostrom and Basurto, 2011) and the key informants checklist questionnaire related to Ostrom principles of governance included:- (1) How local resource users define water resource boundaries (i.e. underground water resources apparently accessed in private and communal land and at district boundaries); (2) How self-enforced rules develop and who is involved in the process; (3) Any collective action taken by resource users to prevent water resources and ecosystems from failure; (4) How customary rules and actions are enforced, who enforces them and why; (5) Any conflict over water resources across village and district boundaries (why/if not why not; how conflicts happened, how they were resolved and by whom); and (6) Any support from formal systems (government/NGOs) on strengthening water governance systems (Ostrom, 1990).

\subsection{Statistical Analysis}

Data were analyzed using the Statistical Package for the Social Sciences (SPSS) version 16). Chi-square cross tabulation was used to test the relationship between independent variables (i.e. type of water resources) and dependent variables (existence of water governance, source of infrastructure of each water resources, rules and norms, types of ownership and water extraction technology). A 'two-tailed' prediction was assumed.

\section{RESULTS}

A household survey questionnaire was administered to 74 women and 88 men with a response rate of $93 \%$. Respondents on type of water resource and customary institutions regulating resource users

Thirty-nine households had access to a lake/ large dam or to a pond near such large surface waters. These never became dry and were open access resources (free to all users). Areas with large surface water resources occurred in Salawe (north Shinyanga) and Nyashishi (areas bordering Mwanza city in Misungwi) and along a gulf from Lake Victoria extending to South East Misungwi (Figure 1). 


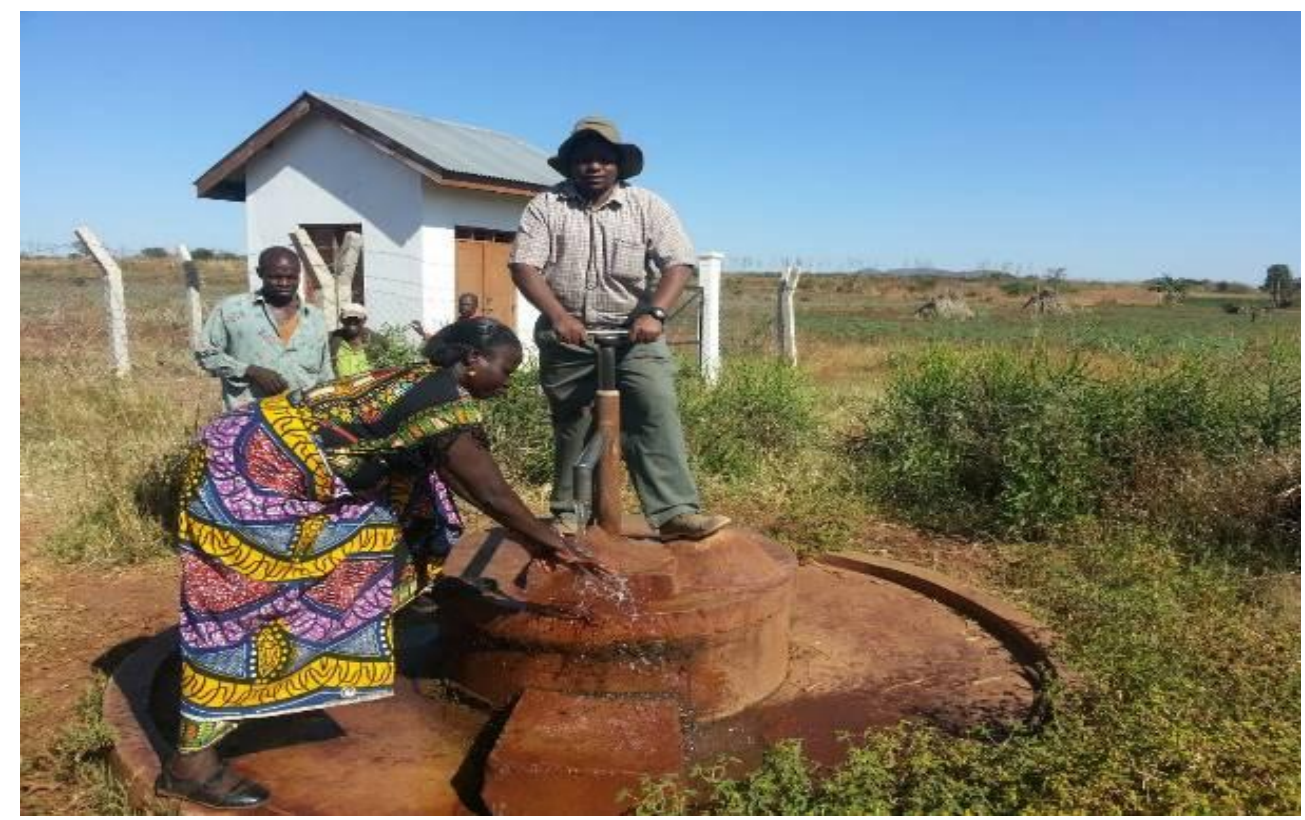

Figure-2. Communal well with hand pump for domestic use in Mwamala village, Shinyanga rural of Tanzania. I is regulated through input contribution to the village water committee, achieved through trained local resource by non-government organizations (NGOs).

Conversely, 132 respondents indicated they had access to three types of water resources (ponds, well and waterholes) which had a very limited capacity to supply water during the dry season and these all had a water management system to govern access (Table 3).

Table-3. Respondents (\%) on type of type of water resource and existence of local water governance systems

\begin{tabular}{l|l|l|l}
\hline Type of water resource & \multicolumn{2}{c}{ Type of ownership } \\
\hline Lake and dam & Communal & Private & Free/open access \\
\hline Ponds near Lake/dam & $\mathrm{O}$ & $\mathrm{O}$ & $22(14)$ \\
\hline Pond & $\mathrm{O}$ & $\mathrm{O}$ & $17(11)$ \\
\hline Well & $31(19)$ & $11(7)$ & $\mathrm{O}$ \\
\hline Waterhole* & $21(13)$ & $17(11)$ & $\mathrm{O}$ \\
\hline$\chi^{2}=229.5, \mathrm{df}=8, \mathrm{p}<0.001$, Source: This study & $43(27)$ & $\mathrm{O}$ \\
\hline Dug in middle of dry sandy riverbeds (open access land, mostly in border of district boundaries) &
\end{tabular}

There was a strong association between whether the water resource had a limited capacity or not and the existence of some form of water governance $\left(\chi^{2}=229.5 \mathrm{df}=8, \mathrm{P}<0.001\right)$, with communities that had access to the two relatively inexhaustible types of water resources (Lake/dam and ponds near these large surface water resources) having little or no water governance. They largely had open access to water and were not further investigated. Thus, subsequent sections describe details of origin of the different water sources under some form of water governance.

\subsection{Types of Water Resources and Existing Communal Water Governance}

Three types of water sources exist and each has some form of communal water governance and use.

\subsubsection{Water Ponds}

Ponds, known locally as malambo, collect surface runoff during the rainy season and normally have no underground water recharge. They are natural depressions, historically known to have been dug by wild animals notably elephants. Others were dug purposely with support from government/NGOs or are accidental manmade depressions created by earth moving equipment taking soil, sand or gravel for construction of highways. 


\subsubsection{Wells}

Two types of wells exist based on design structures and ownership: (a) modern community wells (Figure 2) obtained by drilling a deep well into subterranean aquifers; they generally have an integral mechanical pump and a concrete cap; (b) Private wells dug in wetland (Figure 3); they are mostly wide diameter, unlined or brick-lined and hand-dug by individuals on their private land to access shallow ground water (normally within $10 \mathrm{~m}$ depth).

Water is accessed by buckets or perhaps a separate motorized pump. According to survey respondents, water extraction by private individuals has increased dramatically and historically was not practiced in the area.

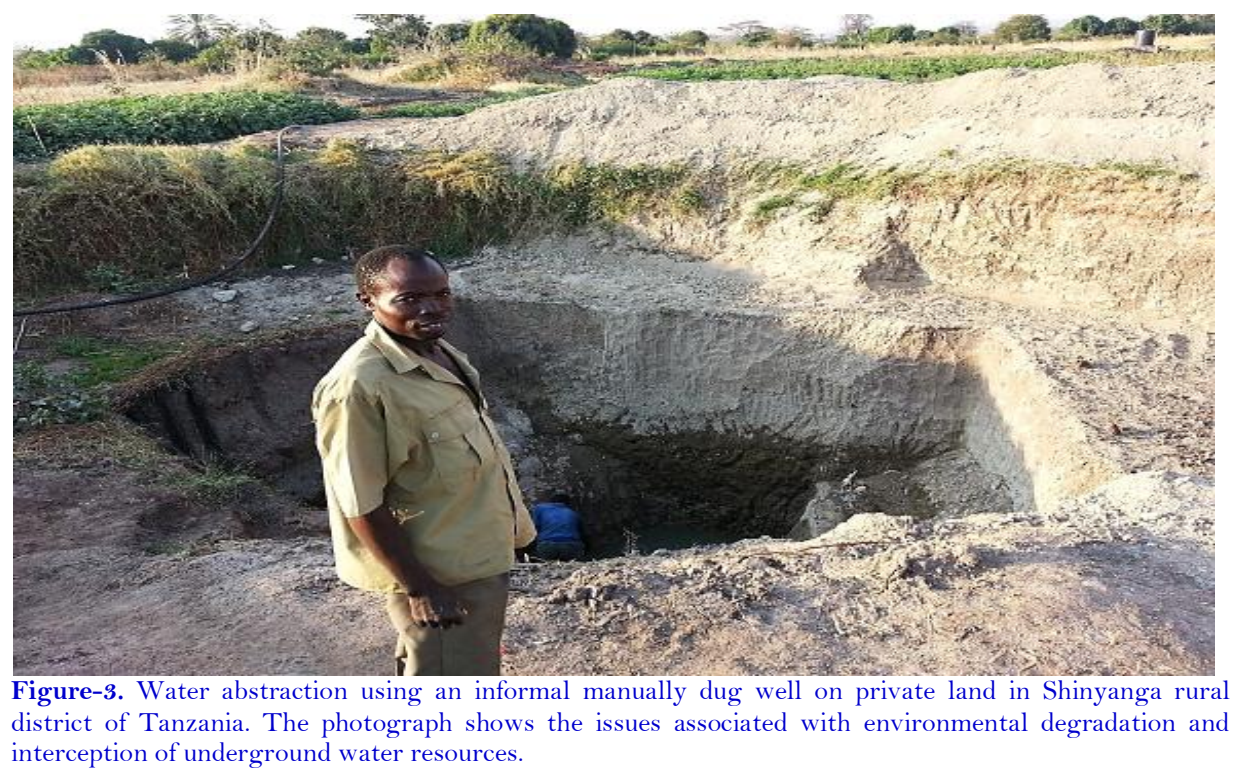

\subsubsection{Waterholes in Sandy Rivers}

These are holes dug in the beds of seasonal sandy rivers (Figure 4). They were mostly used in Meatu and South East Shinyanga Rural districts, notably in areas where water was very scarce. Households access water held in the void between sand particles within 2 to $5 \mathrm{~m}$ depth. Waterholes were re-dug every dry season (between MaySeptember), and reclaimed by floods during the rainy season (December-March). Extracted water was used by the household who dug the well or sold to neighbors for livelihood activities (crop irrigation and stock watering). The waterholes are often dug close together and may compete for the limited water held in the sand; to what extent water is replenished by flow through the sand along the riverbed is unclear.

\subsection{Respondents on Type Water Resources and Origin of Infrastructure}

Water resources managed under communal regulation may be natural or derived from government/NGO activities (Table 4). Privately managed water resources (mainly wells) were from personal investment. They may be natural depressions that collected run-off water on private land or waterholes dug by individuals (personal investment in labour) in open access sandy riverbeds. There was a clear link between the type of ownership of the resource and the origin of the infrastructure $\left(\chi^{2}=90.3, \mathrm{df}=4, \mathrm{P}<0.001\right)$.

Table-4. Number of respondents (\%) on type of water resource and origin of infrastructure

\begin{tabular}{l|l|l|l}
\hline Type of water resource & Origin of infrastructure & Dug by \\
\hline & Nature & Support from government/NGO & O \\
\hline Pond & $\mathrm{O} 24)$ & $12(10)$ & $17(14)$ \\
\hline Well & $10(8)$ & $11(10)$ & $43(35)$ \\
\hline Waterhole* & $\mathrm{O}$ & $\mathrm{O}$ & \\
\hline $\begin{array}{l}\chi^{2}=90.1, \mathrm{df}=4, \mathrm{p}<0.001 \text { Source: This study } \\
\text { *Dug in middle of dry sandy riverbeds (open access land, mostly in border of district and or regional boundaries) }\end{array}$
\end{tabular}




\subsection{Respondents on Type of Ownership and Governance System}

There were two types of ownership of water resources; communal and individual /private (Table 5). Allocation controls - relatively unlimited use but use limited by type, for example, only household use - were mostly used for communally-owned water resources whereas input contributions - monetary or in-kind such as participation in clearing out a waterhole - were mostly used to control water from private sources $\left(\chi^{2}=20.6, \mathrm{df}=1, \mathrm{P}<0.001\right)$. Allocation controls were enforced through penalty with the village council having executive enforcement powers; input contributions were enforced by individual households backed up by village authorities.

Table-5. Respondents (\%) on type of ownership of water resource and type of rules and norms governing resource

\begin{tabular}{l|l|l|l}
\hline Type of ownership & & \multicolumn{1}{l}{ Types of self-enforced rules and norms } \\
\hline & & Input contribution* & Allocation \\
\hline Communal & & $19(15)$ & $33(27)$ \\
\hline Private & $56(46)$ & $15(12)$ \\
\hline $\begin{array}{l}\chi^{2}=20.6, \mathrm{df} \quad 1, \mathrm{p}<0.001 . \text { Source: This study } \\
\text { *Payment fees or participation in digging or maintenance of water resource infrastructures, land ploughing and other cash in-kind } \\
\text { contribution. }\end{array}$
\end{tabular}

\subsection{Respondents on the Main Use of Water and the Type of Water Resource}

The main actual use for water was stock, followed by household, then crops. Communally-owned wells were usually reserved for household use, ponds were mostly used by animals whereas waterholes in riverbeds were used similarly by households, livestock and crops (Table 6$)\left(\chi^{2}=32.9, \mathrm{df}=4, \mathrm{P}<0.001\right)$.

Table-6. Respondents (\%) in type of water resource and main use for water by three sectors (human, stock watering and crop use)

\begin{tabular}{l|l|l|l}
\hline Type of water source & Household & Livestock & Crop use \\
\hline Pond & 0 & $28(23)$ & $14(12)$ \\
\hline well & $21(1$ & $11(9)$ & $6(6)$ \\
\hline Waterhole & $14(11)$ & $15(12)$ & $14(11)$ \\
\hline
\end{tabular}

$\chi^{2}=32.9, \mathrm{df}=4, \mathrm{p}<0.001$. Source: This study

\section{DISCUSSION}

\subsection{Existence of Local Water Governance}

In the absence of formal water institutions and commercial water companies in most rural villages in semi-arid areas of the Lake Zone of Tanzania, increasing water scarcity in the dry season served as an incentive for the evolution of some form of local water governance. Conversely, there appeared to be no water governance in areas with abundance water resources throughout the year (Figure 1). This agrees with Ostrom's economic theory that, as a resource becomes scarce, users tend to organize themselves to prevent it being exhausted (Ostrom, 1990).

\subsection{Ownership of Water Resources and Origin of Infrastructure}

During the dry season, communities in rural areas (Figures 3 and 4) rely mostly on underground water which raises a debate on ownership of such water resources. Tanzania established water rights based on Water Policy of 2002, Water Resource, and Sanitation Act of 2009 (URT, 2013). The two legal documents identify Water Boards as the main owners of subterranean and large surface areas of water and puts emphasis on adequate access to clean water for domestic use as a basic fundamental need. However, these policy documents have largely remained on paper, with little done on the ground. Similar poor water regulation has been documented elsewhere, notably in developing countries elsewhere in Africa and in South Asia. In India for instance, most underground water resources are actually controlled privately (Shah, 2009; Packialakshmi et al., 2011). 


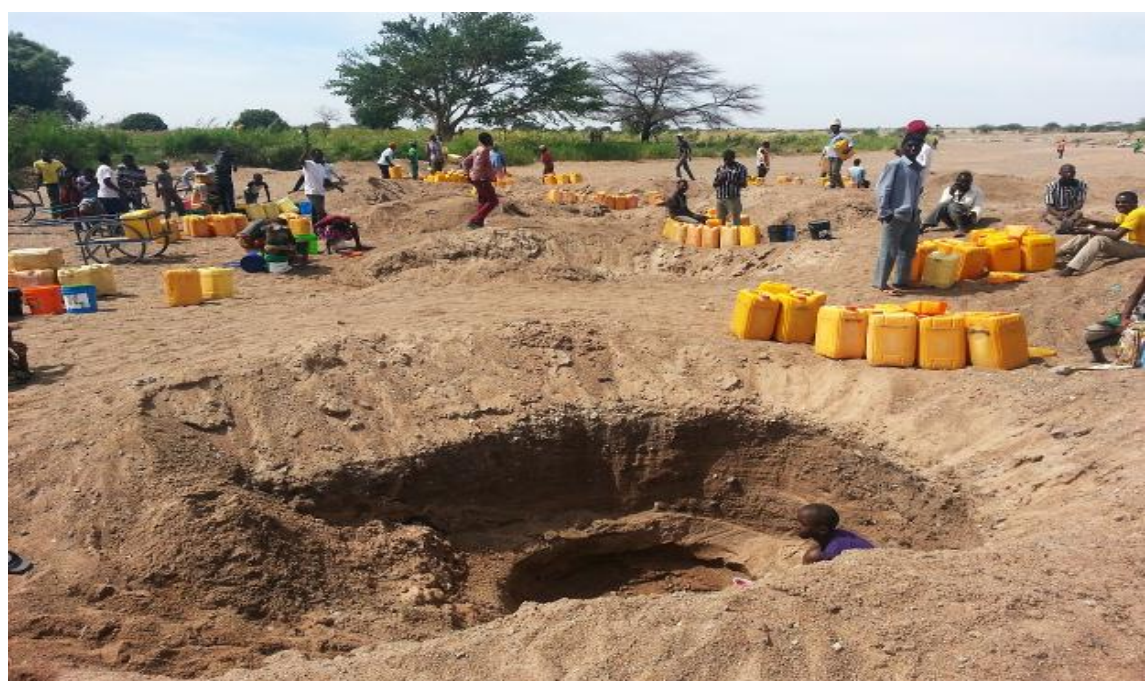

Figure-4. Households accessing water from several waterholes dug within dry sandy riverbed in Meatu district of Tanzania. The photo highlights there are two types of water scarcity in the study area:-too little available to meet the growing demand and social dilemmas in managing the little available equitably.

\subsection{Water Governance Systems and Social Dilemmas}

In the absence of formal water governance in the study area, this survey used information validated from survey questionnaire, focus group discussion and field observations to explore in detail the informal systems of water governance and management. The key question was: How do these rural communities regulate the use of scarce water resources?

Based on data collected from 123 households where there are seasonal water shortages, local resource users developed rules and norms described in Table 5. Use (other than by the owners) of private water extraction units (well and waterholes) are regulated mainly through input contribution. Usually, well and waterholes owners sell water for economic use, notably stock watering and small-scale irrigation activities through input contribution /payment; nonetheless, a neighbor needing water for drinking could usually access it for free (allocation). By contrast, most communal water resources (pond and well with hand pump) are regulated through allocation; wells with a hand pump (Figure 2) are normally used for domestic (human) consumption while ponds are used for stock watering and less frequently for small scale irrigation. Such findings are consistent with practices elsewhere in informal system to manage property resources (Ostrom, 1990). Such informal water management systems have largely been practiced in developing countries and in particular, in several countries from South Asia and Sub Saran Africa. For instance, customary social arrangement among small scale irrigators among two communities in Lombok Island in Indonesia (Sjaha and Baldwin, 2014) and small homogenous communities from semi-arid areas of Northern Tanzania (Komakech and van der Zaag, 2013; Caretta, 2015). However, whether they are 'fair' seems questionable, not least because the water being allocated or sold is theoretically government-owned. In the study area, local village authorities have been struggling in addressing social dilemmas emerging from water resources which are discussed below.

\subsubsection{Three Competing Sectors on Depleting Water Resources}

Rainfall data, water consumption and hydrological data were not available for this study but respondents on the main use of water were used (Table 6). A community well is for household use (free access with no service charges paid). This, however, has created a competition for water with most community wells being over-extracted mostly by youths who transport it to prominent roadside locations where it is sold for domestic use whilst nearby households struggled to access water for personal domestic use. Similar growing informal water markets for domestic use has been documented elsewhere in developing countries, notably in most of states in South and Central Asia where demand is increasing due to declining underground water resources (Manjunatha et al., 2011). 
Water for human consumption is even outcompeting water use for small scale irrigation (Packialakshmi et al., 2011) including in Bangladesh where recent use of tube wells has depleted underground water resources (Sakiur et al., 2016).

Ponds are dominated by livestock owners who access water for free while little attention is given to crop watering. Small scale irrigators trying to extract water for crops are sometimes beaten by stock herders or their crops eaten by livestock. In south Meatu district at least 6 farmers were killed and hundreds injured by stock herders during competition for water. Similar water conflicts have been reported in central Tanzania where at least 40 people were killed in 2008 in Kilosa district (Benjamin et al., 2009). This behavior has resulted in high stocking densities by a few livestock owners, frequent crop failures of many crop owners and massive stress. When households explored opportunities to extract water in wetlands and dry sandy riverbeds, that in turn, created more social dilemmas as described below.

\subsubsection{Impact of Individual Underground Water Extraction in Wetlands}

Unregulated underground water extraction in wetlands (Figure 3) is probably resulting in such water resources declining and such practice may threaten the livelihoods of the future generations if underground aquifers are being tapped. According to interviewed households, such a practice has not been widely practiced until recently. This study estimates that at least 10,500 small scale private irrigators in semi-arid areas of Lake Zone Tanzania access water for livelihoods activities in wetlands by intercepting underground water resources and this number is expected to double by 2020. Albeit an economic opportunity for small scale private individual, unregulated abstraction seems likely to lead to water exhaustion and environmental degradation (de Fraiture and Giordano, 2014) and social problems such as conflicts due to uncontrolled interception of underground resources. Similar worst case scenario is apparent in other parts of the world, notably Asia. In Gujarat State in India for instance, open access underground water resources and subsidies for electricity for pumping water have led to depletion by private households driven by economic interest and abstraction of water for trading (Shah, 2009; Sakiur et al., 2016). According to Tanzania Water Policy 2002 (URT, 2013) any individual or company must acquire water extraction permit from the Water Board, the main formal water institution but this is seldom enforced, perhaps because, as elsewhere, it is unenforceable, undermining policy makers. Exploitation of resources in sandy river beds raises both social and technical questions over resource boundaries since there is little information on hydrology. For instance, while every household is free to dig a private hole and regulate units extracted from it (i.e. own use or trading for economic use), the water in the sandy river bed (the actual resource) is open access. At the same time, it is not known to what extent the water is simply held in the sand and to what extent it is being recharged by flow along the riverbed within the sand, with likely interception of water which would have been used downstream. Bucket and engine are the main water extraction technologies used to extract water; clearly an engine powered pump can extract large quantities of water and this seems likely to be to the detriment of smaller users. Farmers who use engines are relatively rich compared to those using buckets. Those using engines may want to exploit temporary water resources to accumulate savings (wealth) from the irrigation of horticultural crops. Similar selfish behavior has been documented elsewhere in the developing world, notably from South Asia where relatively rich households over-extract water using better technologies (tube wells) and as the results, leads to decline in water availability for other agricultural use (Packialakshmi et al., 2011); a recent study in Bangladesh documented how over-extraction of water resources by private individuals will affect future generations (Sakiur et al., 2016).

\section{CONCLUSION AND RECOMMENDATION}

This study carried out a socio-economic analysis of water governance systems to determine the existence and functioning of informal water governance systems. Where water is abundant (lake/dam and ponds near these water sources), there is no water governance; where water is scarce (ponds, wells and water holes), local resource users 
have incentives to formulate local rules and norms (input, allocation and penalty) to regulate units extracted. However, such communal water governances has several weakness and overall a conclusion can be drawn that local water governances are challenged with: (1) Seasonal water crisis; and (2) Social dilemmas on how to manage equitably the little available. This study describes the two challenges and recommends the following:

\subsection{Increasing Access to Water to Meet the Demand of Three Sectors (Human, Livestock and Crop Use)}

Water is often in super-abundance during the rainy season (December- April) with raging rivers (leading to expanses of sandy riverbeds) and flooding. Nonetheless, during a long dry season (May-November) there is insufficient to meet the demand of the three sectors with communities often undergoing a water crisis. Identifying the potential of capturing runoff during the rainy season to use during the period of water scarcity (MayNovember) is important. Indeed, the easiest immediate solution is to maximize the potential of sandy riverbeds to store water. Thus, construction of several subsurface sand/water storage dams is recommended.

The hydrology of subsurface water storage technology is available in developing countries and recommended as a low evaporation (water is stored between sandy particles), relatively low cost and easy to construct structure when compared with surface dams (Hut et al., 2008; Ertsen and Hut, 2009). In Kitui province in Kenya for instance, over 500 surface dams were constructed by communities in collaboration with local NGOs and increased availability of water by three fold (Quilis et al., 2009). Nonetheless, many small or a few large surface dams may be able to hold back much greater quantities of water. The interviewed local government authorities showed willingness to collaborate with local communities but this requires further technical studies (hydrology)

\subsection{Social Dilemmas on Managing too Little Available Equitably}

Due to increasing number of users, and rapid changes in water extraction technology in semi-arid areas, the quantity abstracted is higher than quantity that can be sustained. The existing informal water governance cannot address this due to social-ecological complexities.

Sandy river beds for instance, are often being located in boundaries between districts or regions, with enormous holes dug by local resource users from both sides, with richer individuals with access to engine-driven pumps digging deeper and with water flowing towards the deeper hole. Ponds are dominated by stock owners. In such a context, a nested approach suggested by development and anthropologist scholars is recommended (Ostrom and Basurto, 2011) by inserting a layer of community self-selected water governance committees to regulate resource users at higher level, notably across district boundaries and each backed up by local district councils. According to Tanzania water laws, Water Board has the mandate to regulate water rights, including issuing underground water extraction permits and diversion of river flows (URT, 2013).

This needs a policy transformation with decentralization of water rights to give much more autonomy to informal water governance. Water trading exists in the study area, with people paying money to access water for humans, stock and crops. However, water is a mobile resource, has to be given an economic value at source and by quantity (not just for access) and rights for extraction have to be as flexible as possible in order accommodate complex socio-ecological issues (Young (2014).

Funding: This study was financed by Natural Resources Institute, University of Greenwich, Chatham Maritime, Kent, ME4, 4TB, United Kingdom through Vines as a Business project (The Bill and Melinda Gate Foundation Project \# OPP1080975) for which the authors are thankful.

Competing Interests: The authors declare that they have no competing interests.

Contributors/Acknowledgement: The authors acknowledge the anonymous reviewers whose useful comments and suggestions helped in improving the quality of this paper. Furthermore, the donor has no any influence in publication of this paper. 


\section{REFERENCES}

Benjamin, T.A., F.P. Maganga and J.M. Abdallah, 2009. The Kilosa Killings: Political ecology of a farmer-herder conflict in Tanzania. Development and Change, 40(3): 423-445. View at Google Scholar | View at Publisher

Caretta, M.A., 2015. Managing variability and scarcity. An analysis of Engaruka: A Maasai smallholder irrigation farming community. Agricultural Water Management, 159: 318-330. View at Google Scholar | View at Publisher

de Fraiture, C. and M. Giordano, 2014. Small private irrigation: A thriving but overlooked sector. Agricultural Water Management, 131: 167-174. View at Google Scholar | View at Publisher

Ertsen, M.W. and R. Hut, 2009. Two waterfalls do not hear each other. Sand-storage dams, Science and sustainable development in Kenya. Physics and Chemistry of the Earth, 34(1-2): 14-22. View at Google Scholar | View at Publisher

FAO, 2010. Manual on small earth dams. A guide to siting, design and construction. Retrieved from http://www.fao.org/docrep/012/i1531e/i1531e.pdf [Accessed 22 July 2016$]$.

Food and Agriculture Organization of the United Nations (FAO), 2015. Global population and water withdrawal over time. Retrieved from http://www.fao.org/nr/water/aquastat/water use/image/WithTimePopAxis eng.pdf [Accessed 22 July 2016$]$.

Giordano, M. and T. Shah, 2014. From IWRM back to integrated water resources management. International Journal of Water Resources Development, 30(3): 364-376. View at Google Scholar | View at Publisher

Global Water Partnerships (GWP), 2012. Towards a water secure world. Integrated water resources management (IWRM) principles. Retrieved from http://www.gwp.org/en/The-Challenge/What-is-IWRM/IWRM-Principles/ [Accessed 28 December $2016]$.

Hu, X., Y. Xiong, J. Li, J. Wang, F. Li, H. Wang and L. Li, 2014. Integrated water resources management and water users' associations in the arid Region of Northwest China: A case study of farmers' perceptions. Journal of Environmental Management, 145: 162-169. View at Google Scholar | View at Publisher

Hut, R., M. Ertsen, N. Joeman, N. Vergeer, H. Winsemius and N. Van de Giesen, 2008. Effects of sand storage dams on ground water levels with examples from Kenya. Physics and Chemistry of the Earth, 33(1-2): 56-66. View at Google Scholar| View at Publisher

Ittersum, V.M.K., V.L.G.J. Bussel, J. Wolf, P. Grassini, V.J. Wart, N. Guilpart, L. Claessens, D.H. Groot, K. Wiebe, C.D. Mason, H. Yang, H. Boogaard, V.P.N.J. Oort, V.M.P. Loon, K. Saito, O. Adimo, S. Adjei-Nsiah, A. Agali, A. Bala, R. Chikowo, K. Kaizzi, M. Kouressy, K. Sauto, O. Adimo, S. Adjei-Nsiah, A. Agali, A. Bala, R. Chikowo, K. Kaizzi, M. Kouressy, J.H.J. Makoi, K. Quattara, K. Tesfaye and K.G. Casmman, 2016. Can Sub Saharan Africa feed by itself? Proceedings of the National Academy of Sciences of the United States of America, 113: 14964-14969.

Jenniver, S., 2007. Irrigation reform in Kyrgyzstan and Tajikistan. Irrigation and Drainage Systems, 21(3-4): 277-290. View at Google Scholar | View at Publisher

Komakech, H.C. and P. van der Zaag, 2013. Polycentrism and pitfalls: The formation of water users forums in the Kikuletwa catchment, Tanzania. Water International, 38(3): 231-249. View at Google Scholar | View at Publisher

Kyei-Buffour, N. and E. Ofori, 2006. Irrigation development and management in Ghana: Prospects and challenges. Journal of Science and Technology, 26(2): 148-159. View at Google Scholar | View at Publisher

Lukonge, J.E., W.R. Gibson, L. Laizer, R. Amour and D.P. Philips, 2015. Delivering new technologies to the Tanzanian sweetpotato crop through its informal seed system. Agroecology and Sustainable Food Systems, 39(8): 861-884. View at Google Scholar View at Publisher

Manjunatha, A.V., M.G. Speelman, M.G. Chandrakanth and G. Van Huylenbroeck, 2011 . Impact of groundwater markets in India on water use efficiency: A data envelopment analysis approach. Journal of Environmental Management, 92(11): 2924-2929. View at Google Scholar | View at Publisher

Maxwell, J.A., 2013. Qualitative research design: An interactive approach. Los Angeles: Sage.

Mehari, A., B.V. Koppen, M. McCartney and B. Lankford, 2009. Unchartered innovation? Local reforms of national formal water management in the Mkoji sub-catchment, Tanzania. Physics and Chemistry of the Earth, 34(4-5): 299-308. View at Google Scholar | View at Publisher 
Mekonnen, M.M. and A.Y. Hoekstra, 2016. Four billion people facing severe water scarcity. Science Advances, 2(2): e1500323. View at Google Scholar | View at Publisher

Mosha, B.D., C.G. Kajembe, A.K.P.R. Tarimo, P. Vedeld and G.E. Mbeyales, 2016. Performance of water management institutions in farmer-managed irrigation schemes in Iringa rural and Kilombero Districts, Tanzania. International Journal of Asian Social Science, 6(8): 430-445. View at Google Scholar | View at Publisher

National Bureau of Statistics (NBS), 2012. Tanzania population and housing census. Population distribution by administrative areas. Dar es Salaam, Tanzania: National Bureau of Statistics and Office of the Chief Government Statistician.

North, D., 1990. Institutions, institutional change, and economic performance. New York: Cambridge University Press.

Ostrom, E., 1990. Governing the commons: Evolution of institutions for collective action. New York: Cambridge University Press.

Ostrom, E. and X. Basurto, 2011. Crafting analytical tools to study institutional change. Journal of Institutional Economics, 7(3): 317343. View at Google Scholar | View at Publisher

Packialakshmi, S., N.K. Ambujam and N. Prakash, 2011. Groundwater market and its implications on water resources and agriculture in the Southern peri-urban interface, Chennai, India. Environment, Development and Sustainability, 13(2): 423-438. View at Google Scholar | View at Publisher

Quilis, R.O., M. Hoogmoed, M. Ertsen, J.M. Foppen, R. Hut and A. de Vries, 2009. Measuring and modeling hydrological processes of sand-storage dams on different spatial scales. Physics and Chemistry of the Earth, 34(4-5): 289-298. View at Google Scholar View at Publisher

Quinn, C.H., M. Hubby, H. Kiwasila and J.C. Lovert, 2007. Design principles and common pool resource management: An institutional approach to evaluating community management in semi-arid Tanzania. Journal of Environmental Management, 84(1): 100113. View at Google Scholar | View at Publisher

Sakiur, R., K. Md., J. Chowdhury and M. Quamrul, 2016. Long-term trend analysis of water table using 'MAKESENS' model and sustainability of groundwater resources in drought prone Barind area, NW Bangladesh. Journal of the Geological Society of India, 87(2): 179-193. View at Google Scholar | View at Publisher

Shah, T., 2009. Taming the anarchy: Groundwater governance in South Asia. Washington, DC, USA: RFF Press.

Sjaha, T. and C. Baldwin, 2014. Options for future effective water management in Lombok: A multi-level nested framework. Journal of Hydrology, 519: 2448-2455. View at Google Scholar | View at Publisher

Swatuk, L., 2005. Political challenges to implementing IWRM in Southern Africa. Physics and Chemistry of the Earth, 30(11-16): 872880. View at Google Scholar | View at Publisher

Tong, X., H. Pan, H. Xie, X. Xu, F. Li, L. Chen, X. Luo, S. Liu, P. Chen and Y. Jin, 2016. Estimating water volume variations in Lake Victoria over the past 22 years using multi-mission altimetry and remotely sensed images. Remote Sensing of Environment, 187: 400-413. View at Google Scholar | View at Publisher

United Republic of Tanzania (URT), 2013. Water sector development programme. Tanzania, Dar es Salaam: Ministry of Water and Irrigation.

Weiss, M.I., 2015. A perfect storm: The causes and consequences of severe water scarcity, Institutional breakdown and conflict in Yemen. Water International, 40(2): 251-272. View at Google Scholar | View at Publisher

Xie, H., L. You and C.R. Wielgosz, 2014. Estimating the potential for expanding smallholder irrigation in Sub-Saharan Africa. Agricultural Water Management, 131(1): 183-193.

Young, M.D., 2014. Designing water abstraction regimes for an ever-changing and ever-varying future. Agricultural Water Management, 145: 32-38. View at Google Scholar | View at Publisher

Views and opinions expressed in this article are the views and opinions of the author(s), International Journal of Asian Social Science shall not be responsible or answerable for any loss, damage or liability etc. caused in relation to/arising out of the use of the content. 